\title{
HUBUNGAN ANTARA KARAKTERISTIK INDIVIDU UNIT KERJA DAN FAKTOR ERGONOMI DENGAN KELUHAN KESEHATAN DI INDUSTRI KECIL SEPATU KOTA MOJOKERTO
}

\author{
RELATIONSHIP BETWEEN INDIVIDUAL CHARACTERISTICS OF \\ WORKING UNIT AND ERGONOMIC FACTORS WITH HEALTH \\ COMPLAINTS IN SMALL INDUSTRY SHOES MOJOKERTO CITY
}

\author{
Margaretta Frizka, Tri Martiana \\ Departemen Keselamatan dan Kesehatan Kerja \\ Fakultas Kesehatan Masyarakat Universitas Airlangga \\ E-mail: margarettafrizka@gmail.com
}

\begin{abstract}
Study of health complaint for shoes makers have been made in UD Wardana Mojokerto City. The purpose of the study were to identify individual and environmental factor associated with health complaint. This study was an observational descriptive with cross sectional approach. The respondents were all shoes makers that worked in UD Wardana Mojokerto city $(N=28)$. Variables of this study were individual characteristics (age, duration of employments, regular physical exercise, and smoking habit), work section, and ergonomic factors (work posture, static sitting, posture of sitting, static standing, and posture of standing). The data were collected and analyzed with chi-square and contingency coefficient. The results that most of the respondents were aged 19-27 years (46.43\%), duration of employment 1-5 years (46.43\%) didn't take regular physical exercise (68.57\%), and non smoker (78.57\%). There were strong association between respiration complaint with age $(C=0.535)$, duration of employment $(C=0.509)$. Musculoskeletal complaint with static sitting $(C=0.544)$, static standing $(C=0.559)$, and body posture $(C=0.559)$. From the findings, It is concluded that shoes makers have risk of musculoskeletal and respiratory complaints.
\end{abstract}

Keywords: ergonomic factors, health complaints, shoes makers, individual characteristics

\begin{abstract}
ABSTRAK
Studi tentang keluhan kesehatan pada pekerja sepatu telah dilakukan di UD Wardana Kota Mojokerto. Tujuan dari penelitian adalah untuk menganalisis hubungan faktor individu dan lingkungan dengan keluhan kesehatanPenelitian ini adalah deskriptif observasional dengan pendekatan cross sectional. Responden adalah semua pekerja sepatu yang bekerja di UD Wardana Kota Mojokerto $(\mathrm{N}=28$ ). Variabel dari penelitian ini adalah karakteristik individu (umur, masa kerja, kebiasaan olahraga dan kebiasaan merokok), unit kerja dan faktor ergonomi (postur kerja, duduk statik, postur duduk, berdiri statik dan postur berdiri). Hasilnya adalah sebagian besar pekerja berusia 19-27 tahun (46,43\%), masa kerja 1-5 tahun $(46,43 \%)$ tidak olahraga teratur $(68,57 \%)$, bukan perokok $(78,57 \%)$ Terdapat hubungan yang kuat antara keluhan pernapasan dengan usia $(C=0,535)$, masa kerja $(C=0,509)$. Keluhan muskuloskeletal dengan duduk statik $(C=0,544)$, berdiri statik $(C=0,559)$, dan postur tubuh $(C=0,559)$. Berdasarkan temuan, dapat disimpulkan bahwa pekerja sepatu berisiko mengalami keluhan muskuloskeletal dan pernapasan.
\end{abstract}

Kata kunci: faktor ergonomi, keluhan kesehatan, pekerja sepatu, karakteristik individu

\section{PENDAHULUAN}

Industri kecil di Indonesia mengalami perkembangan yang signifikan khususnya pada industri sepatu. Sepatu dan alas kaki adalah salah satu komoditi andalan ekspor yang bersifat padat karya dengan jumlah tenaga kerja yang terserap sebesar 414.930 pekerja, dan nilai total ekspor tahun
2007 sebesar US\$1,6 miliar. Selain itu bersifat padat karya (Aprisindo, 2008).

Tahapan dalam pembuatan sepatu adalah pembuatan dan pemotongan pola, pengeleman, penjahitan, pemberian lapisan sepatu, pengepakan dan pemasaran. Bahan yang digunakan antara lain kulit sintetik, sol sepatu, dan lem. Pada proses 
produksi sepatu, lem sepatu yang dipergunakan adalah lem kuning dan lem putih (Didin, 2007). Salah satu proses kerja yang berisiko terhadap kesehatan ada pada proses pengeleman karena pajanan pelarut organik dalam lem. Hal tersebut dibuktikan melalui beberapa penelitian yang menunjukkan hubungan yang kuat antara pajanan pelarut organik dengan penyakit tertentu pada pekerja (Hamilton, 2005).

Senyawa BTX (Benzena, Toluen dan Xilen) merupakan bahan penting dalam industri sepatu. BTX merupakan komponen utama dalam lem, pelarut dan juga cat yang digunakan di industri sepatu (Martha, 2012). Berdasarkan penelitian diketahui terdapat pelarut organik dalam lem berupa toluena lebih dari $70 \%$ dan pelarut benzena sekitar 1-2\%. Efek kesehatan akut yang ditimbulkan oleh pajanan pelarut organik adalah gangguan terhadap sistem saraf pusat (SSP). Paparan dalam jangka pendek, dapat menimbulkan efek depresi SSP. Paparan dengan dosis rendah mengakibatkan depresi SSP ditandai dengan gejala mual, muntah, pusing dan sakit kepala. Bila terpajan dosis tinggi gejala yang timbul antara lain gemetar (tremor), lemah atau lemas, tekanan darah yang labil, sakit kepala (berat), serangan pusing secara tiba-tiba, vertigo, muntah, dehidrasi dan dampak yang paling buruk adalah kematian (Widjaja, 2008).

Berdasarkan hasil penelitian yang telah dilakukan pada pekerja sepatu di Tasikmalaya, diperoleh hasil sebagian besar mengalami gangguan pernapasan (70\%) akibat menghirup uap lem dan debu dalam waktu yang lama. Keluhan lain yang dirasakan yaitu kejang lengan (26\%), pusing $(20 \%)$, batuk dan mudah lelah (19\%), iritasi kulit (9\%), dan masalah pernapasan (7\%). Penelitian lain yang dilakukan oleh Kurniawidjaja (2012) pada pekerja di bengkel alas kaki kecil, diketahui sebanyak $25 \%$ pekerja wanita didiagnosis menderita penyakit kulit, $39,4 \%$ mengalami batuk, $54,5 \%$ pilek, dan $27,3 \%$ mengalami sesak napas.

Posisi tubuh saat bekerja sangat ditentukan oleh jenis pekerjaan yang dilakukan. Masing-masing posisi kerja memberikan pengaruh yang berbeda terhadap tubuh. Sikap kerja duduk memerlukan energi yang lebih sedikit daripada sikap berdiri sehingga beban pada otot statis dapat dikurangi (Nurmianto, 2004). Grandjean (1993) dalam Tarwaka (2010) menyatakan bahwa sikap kerja statis dalam jangka waktu lama lebih cepat menimbulkan keluhan pada sistem muskuloskeletal.
Keluhan muskuloskeletal ditandai dengan sakit, nyeri, mati rasa, kesemutan, bengkak, kekakuan, gemetar, gangguan tidur dan rasa terbakar. Keluhan muskuloskeletal yang tidak segera ditangani maka mengakibatkan timbulnya penyakit otot rangka atau Musculoskeletal Disorders (MSDs) (Humantech, 1995). MSDs meliputi low back pain, cervic spindolisis, carpal tunnel syndrome, dan tennis elbow, serta timbulnya dapat merupakan akibat dari pekerjaan yang dilakukan (Bridger, 1995).

Penelitian yang dilakukan oleh Pusat Riset dan Pengembangan Ekologi Kesehatan Departemen Kesehatan (2004) pada 800 orang dari 8 sektor kecil di Indonesia, menunjukkan hasil bahwa gangguan muskuloskeletal dialami oleh $76,7 \%$ perajin batu bata di Lampung, 41,6\% nelayan di DKI Jakarta, 31,6\% petani kelapa sawit di Riau, 21\% perajin wayang kulit di Yogyakarta, $18 \%$ perajin Onyx di Jawa Barat, 16,4\% penambang emas di Kalimantan Barat, 14,9\% perajin sepatu di Bogor, dan $8 \%$ perajin kuningan di Jawa Tengah. Semua pekerja mengeluhkan nyeri di punggung, bahu, dan pergelangan tangan (Heryanto, 2004). Penelitian lain menyebutkan bahwa diperkirakan angka kejadian LBP berkisar antara 7,6\% hingga 37\% (Prodia dalam Bhaskara, 2011).

Penelitian yang dilakukan oleh Samara di PT. X (2005), diperoleh hasil bahwa sikap tubuh yang cenderung membungkuk atau miring memiliki risiko kejadian nyeri punggung bawah 2,58 kali lebih besar dibandingkan sikap tubuh tegak, sedangkan pada sikap kombinasi antara membungkuk, miring, memutar dan tegak risikonya 2,68 kali. Penelitian lain yang dilakukan oleh Nurhikamah (2011) pada pekerja furniture di Tangerang, diperoleh hasil keluhan pada leher $(50,6 \%)$, tangan kanan (49.4\%), bahu kanan (47\%) punggung (44.4\%) dan pergelangan kaki kanan (35\%). Penelitian lain yang dilakukan oleh Munir (2008) pada pekerja di 3 group pekerjaan di departemen water pump, diperoleh hasil bahwa bagian tubuh yang sering dikeluhkan adalah bagian leher sebesar 100\%, punggung sebesar $79 \%$ dan bahu sebesar $69,7 \%$. Keluhan muskuloskeletal terjadi sebagai akibat dari faktor-faktor pekerjaan, pekerja, psikososial, dan lingkungan (Cohen et al, 1997). Faktor pekerjaan adalah faktor yang berasal dari pekerjaan itu sendiri termasuk gerakan repetitive, beban, postur statis, dan penggunaan tenaga. Faktor pekerjaan berupa umur, lama bekerja, dan riwayat penyakit. Faktor lingkungan kerja yaitu vibrasi, suhu, dan tingkat iluminasi (Bridger, 1995). 
Menurut penelitian yang dilakukan oleh Hanne dan kawan-kawan (1995) pada pekerja perusahaan kayu dan furniture, diketahui bahwa LBP berhubungan dengan usia dan masa kerja yang lebih lama, sedangkan penelitian yang dilakukan oleh Soleha (2009) didapatkan variabel umur dan kebiasaan merokok memiliki hubungan yang bermakna dengan keluhan MSDs. Penelitian lain yang dilakukan oleh Ramli (2005), diperoleh hasil bahwa ada hubungan bermakna antara kebiasaan olah raga dengan keluhan pada bahu. Berdasarkan fakta yang telah ditunjukkan maka peneliti ingin mempelajari serta menganalisis faktor yang berhubungan terhadap keluhan kesehatan pada pekerja sepatu di UD Wardana Kota Mojokerto dengan harapan dapat dijadikan perhatian oleh semua pihak UD Wardana merupakan salah satu industri kecil yang memproduksi sepatu di Kota Mojokerto. Sarana maupun prasarana yang digunakan meliputi alat-alat dan proses produksinya masih sederhana dan belum memenuhi standar kesehatan. Gambaran tempat kerja antara lain ventilasi yang kurang sehingga ruangan terasa pengap dan tercium bau lem yang menyengat. Area kerja yang tidak terlalu luas, namun ditempati oleh banyak pekerja serta tumpukan bahan baku dan bahan jadi yang tidak tertata rapi akibatnya ruang gerak pekerja menjadi terbatas. Kursi yang dipergunakan belum memenuhi standar karena tidak memiliki sandaran tempat duduk dan kursi yang panjang kakinya terlalu rendah. Meja kerja yang dipergunakan terlalu tinggi bagi pekerjaan yang memerlukan tenaga seperti pada bagian pemotongan dan pembuatan sol sepatu.

Proses produksi, masih menggunakan tenaga manusia. Saat melakukan pekerjaannya, pekerja selalu bekerja dalam posisi yang tidak menentu diantaranya berdiri agak membungkuk, duduk di lantai dengan punggung yang terlalu membungkuk atau duduk dengan alat-alat sederhana. Posisi kerja seperti itu sangat berisiko untuk menimbulkan risiko kerja secara ergonomic yang dapat menyebabkan gangguan musculoskeletal disorders (MSDs).

Bahan yang dikerjakan diletakkan di depan tubuh atau diletakkan di tanah/lantai selanjutnya sikap tubuh pekerja menyesuaikan dengan bahan yang dikerjakan. Kondisi kerja seperti ini memaksa pekerja selalu berada pada sikap dan posisi kerja yang tidak alamiah yang berlangsung lama dan menetap/statis. Berdasarkan pengambilan data awal yang dilakukan, dengan wawancara singkat dengan 10 orang pekerja, diketahui bahwa $90 \%$ pekerja mengalami keluhan pada muskuloskeletal, dengan keluhan pada punggung sebesar $50 \%$, punggung bawah $20 \%$, lengan atas dan leher sebesar $10 \%$. Keluhan lainnya adalah keluhan pada pernapasan sebesar $50 \%$.

\section{METODE}

Berdasarkan sifat, penelitian ini merupakan penelitian deskriptif observasional karena peneliti tidak memberi perlakuan khusus kepada responden. Ditinjau dari waktu pengambilan sampel datanya, maka penelitian ini bersifat cross sectional populasi penelitian ini adalah semua pekerja industri sepatu di UD Wardana sebanyak 28 orang. Pengambilan sampel diambil dari seluruh populasi yang ada. Penelitian dilakukan di Industri kecil sepatu UD Wardana, Kota Mojokerto. Waktu penelitian pada bulan April 2013 sampai Januari 2014. Data primer dikumpulkan dengan cara wawancara dengan menggunakan bantuan instrumen kuesioner dan lembar observasi. Data yang didapatkan dari kuesioner kemudian dianalisis dalam tabel dan narasi. Kuat hubungan antar variabel dianalisis secara deskriptif dengan tabel silang dan untuk mengukur kuat hubungan menggunakan nilai koefisien kontingensi (C).

\section{HASIL}

Hasil penelitian diperoleh dari kuesioner meliputi karakteristik pekerja (umur, masa kerja dan kebiasaan olahraga), faktor ergonomi (sikap kerja duduk dan posisi tubuh). Distribusi variabel pada Gambar 1.

Pekerja sebagian besar berumur antara 19-27 tahun, yaitu persentasenya sebesar $46,43 \%$.Pekerja sebagian besar sudah bekerja selama 1-5 tahun yaitu persentasenya sebesar $46,43 \%$. Pekerja sebagian besar tidak memiliki kebiasaan merokok yaitu persentasenya sebesar $78,57 \%$. Pekerja sebagian besar tidak memiliki kebiasaan olahraga yaitu persentasenya sebesar $67,86 \%$. Pekerja sebagian besar melakukan pekerjaan dengan duduk, persentasenya sebesar $50,00 \%$. Pekerja sebagian besar melakukan pekerjaan dengan duduk di lantai, persentasenya sebesar $50,00 \%$. Pekerja sebagian besar yang bekerja dengan berdiri, sebagian besar bekerja dengan menggunakan meja, persentasenya sebesar 21,42\%. Pekerja sebagian besar melakukan pekerjaan dengan punggung membungkuk, persentasenya sebesar $35,71 \%$. 


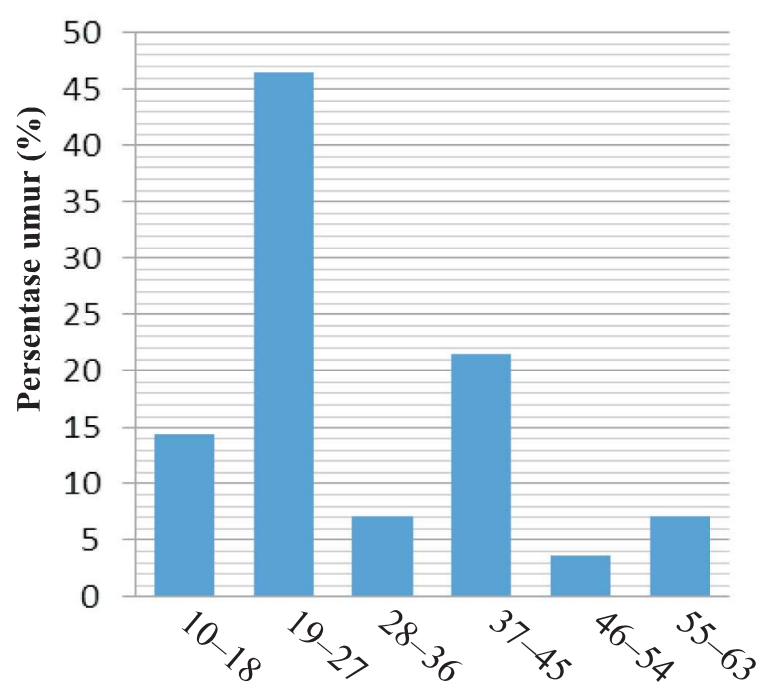

Kelompok Umur Pekerja (tahun)

Gambar 1. Grafik persentase kelompok umur pekerja

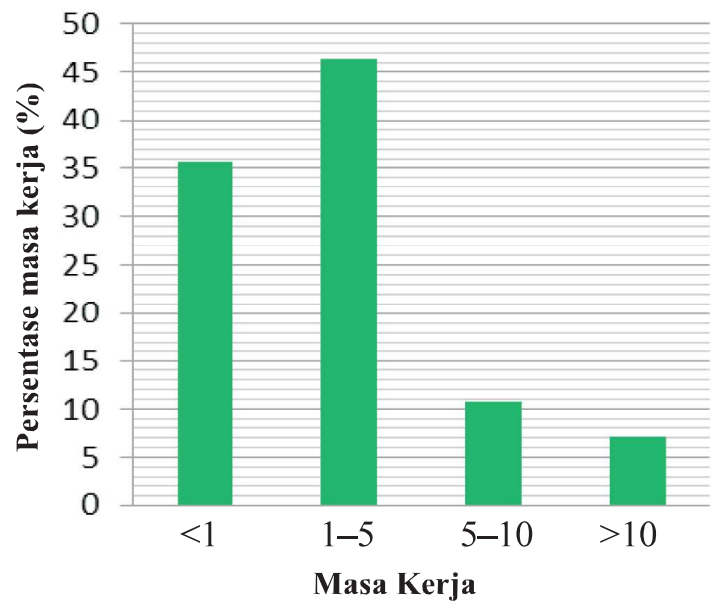

Gambar 2. Grafik persentase masa kerja

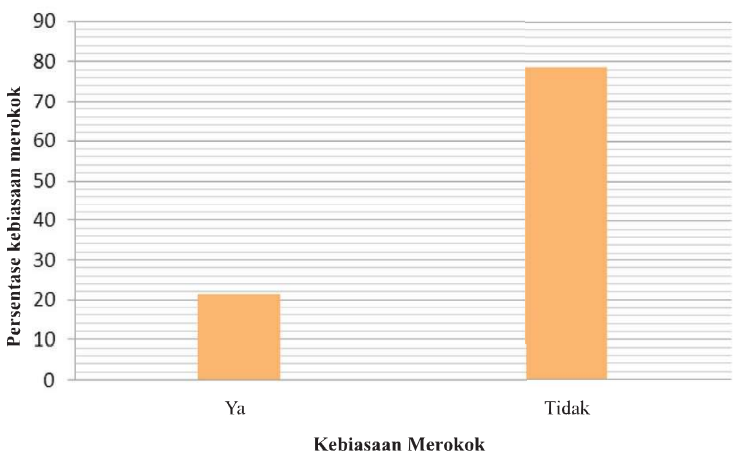

Gambar 3. Grafik persentase kebiasaan merokok

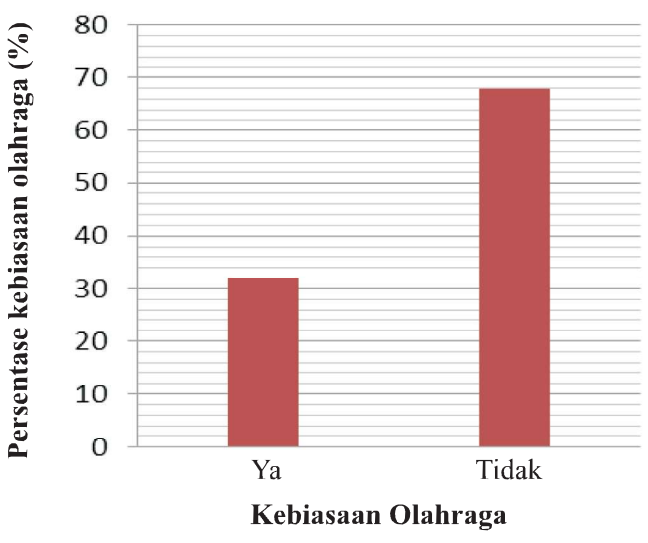

Gambar 4. Grafik persentase kebiasaan olahraga pekerja

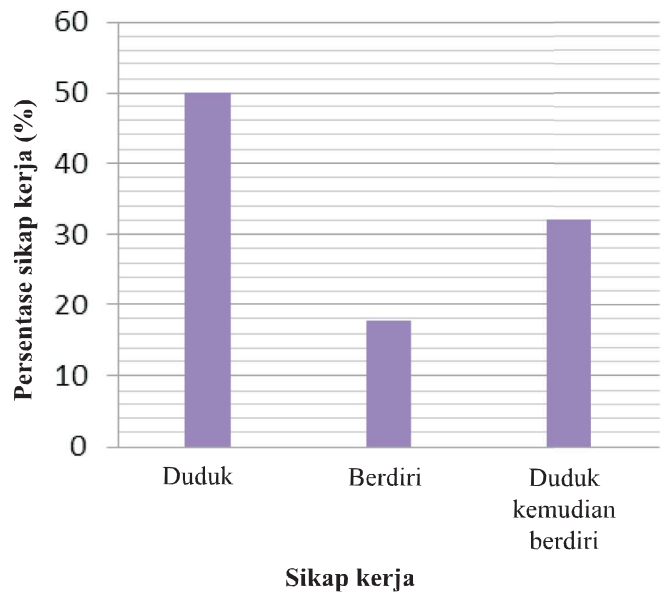

Gambar 5. Grafik persentase sikap kerja

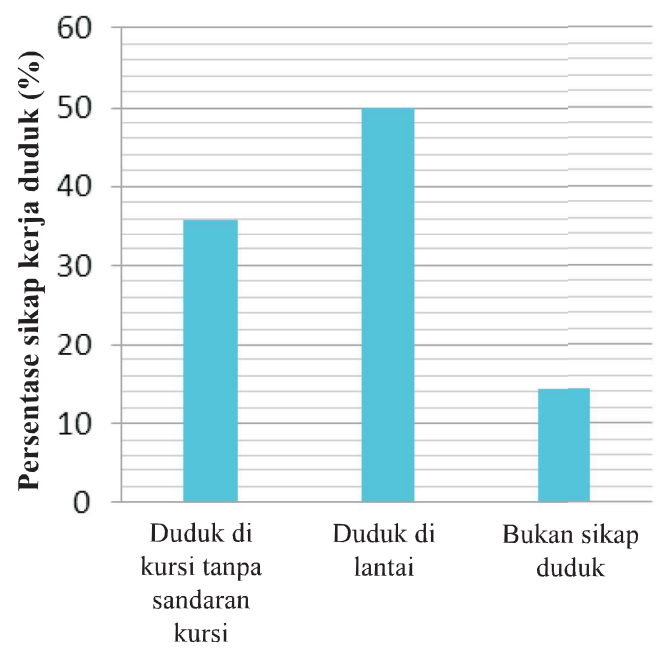

Sikap Kerja Duduk

Gambar 6. Grafik persentase sikap kerja duduk 


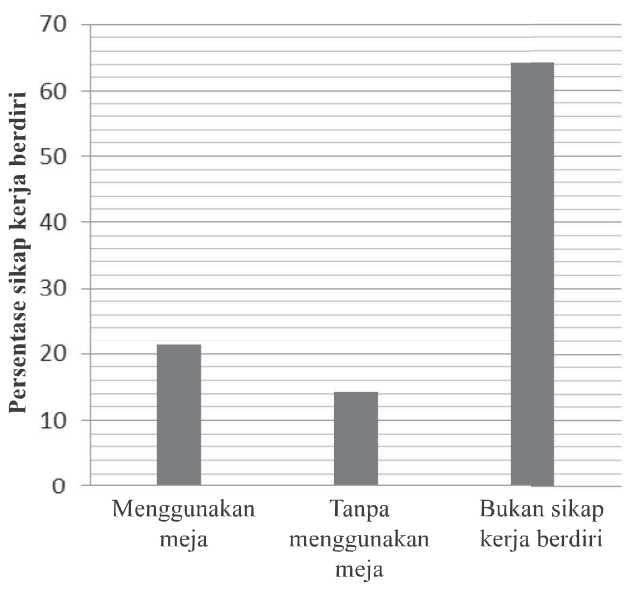

Sikap kerja berdiri

Gambar 7. Grafik persentase keluhan musculoskeletal

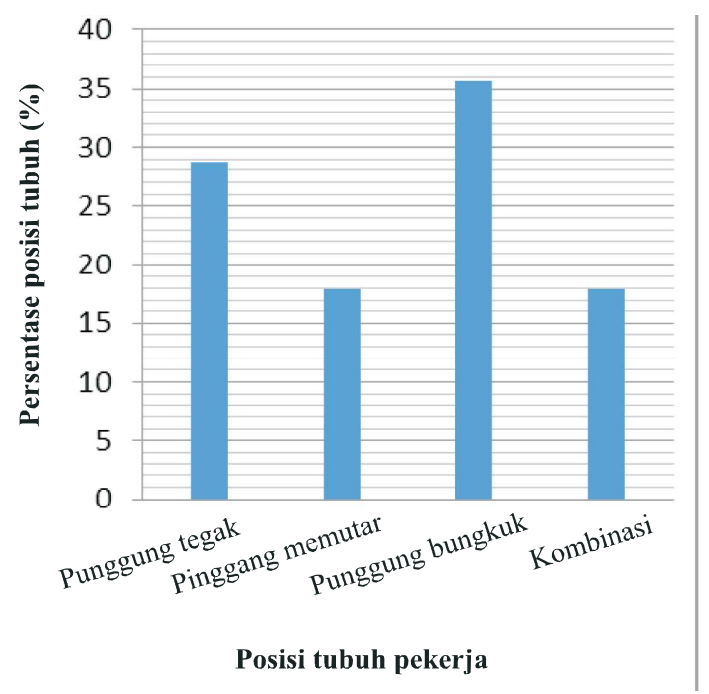

Gambar 8. Grafik persentase posisi tubuh.

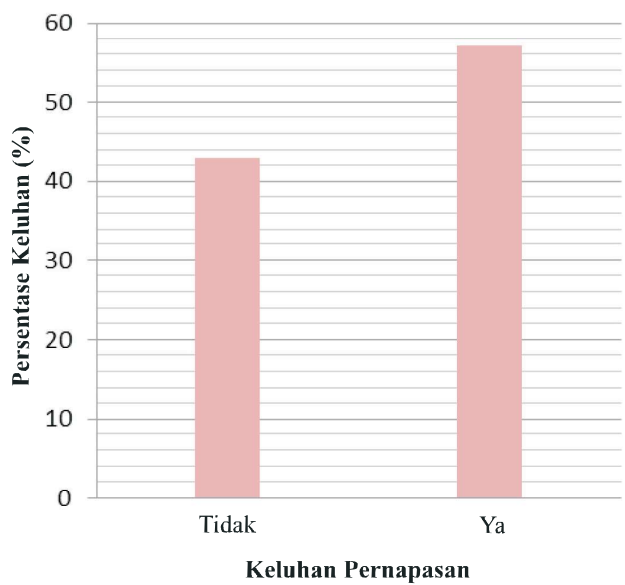

Gambar 9. Grafik persentase keluhan pernapasan

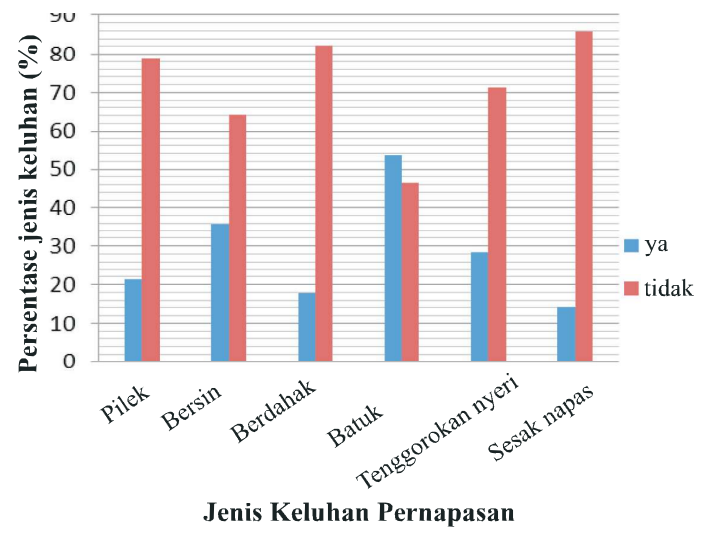

Gambar 10. Grafik persentase jenis keluhan pada pernapasan

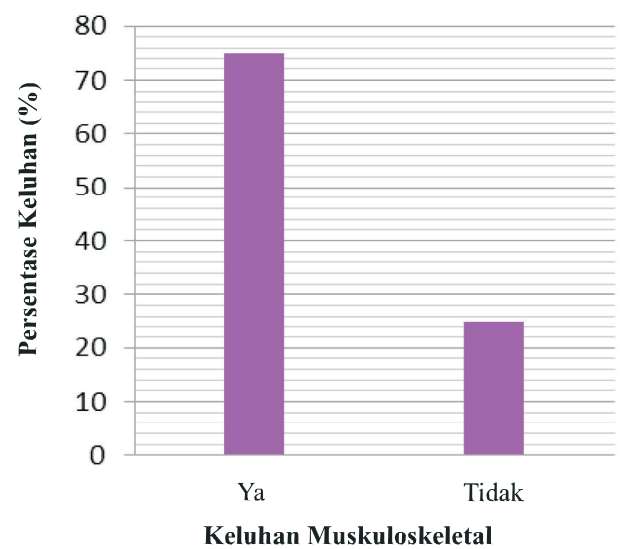

Gambar 11. Grafik persentase keluhan musculoskeletal

Variabel terikat dari penelitian ini adalah keluhan pernapasan dan musculoskeletal pada pekerja. Pekerja sebagian besar mengalami keluhan pernapasan yaitu sebesar $57,14 \%$. Pekerja sebagian besar mengalami keluhan pernapasan batuk yaitu sebesar 53,57\%. Pekerja sebagian besar mengalami keluhan muskuloskeletal yaitu sebesar $71,43 \%$.

Berdasarkan hasil penelitian, dapat diketahui bahwa sebagian besar pekerja mengalami keluhan pada punggung $(71,43 \%)$, kemudian diikuti oleh keluhan pada pinggang sebesar $50,00 \%$. Ada hubungan kuat antara keluhan pernapasan dengan umur dan masa kerja, serta hubungan sedang dengan kebiasaan merokok dan kebiasaan olahraga. Berdasarkan dari hasil penitian, diketahui bahwa ada hubungan kuat antara keluhan muskuloskeletal dengan duduk statis, berdiri statis dan posisi tubuh. 
Tabel 1. Bagian Tubuh yang Mengalami Keluhan

\begin{tabular}{lcc}
\hline \multicolumn{1}{c}{ Bagian Tubuh yang } & \multicolumn{2}{c}{ Hasil } \\
\cline { 2 - 3 } \multicolumn{1}{c}{ Mengalami Keluhan } & n & \% \\
\hline Leher Atas & 7 & 25,00 \\
Leher Bawah & 3 & 10,71 \\
Bahu Kiri & 3 & 10,71 \\
Bahu Kanan & 10 & 35,71 \\
Lengan Atas Kiri & 0 & 0 \\
Punggung & 20 & 71,43 \\
Lengan Atas Kanan & 3 & 10,71 \\
Pinggang & 14 & 50,00 \\
Bokong & 3 & 10,71 \\
Pantat & 0 & 0 \\
Siku Kiri & 0 & 0 \\
Siku Kanan & 0 & 0 \\
Lengan Bawah Kiri & 0 & 0 \\
Lengan Bawah Kanan & 0 & 0 \\
Pergelangan Tangan Kiri & 0 & 0 \\
Pergelangan Tangan Kanan & 0 & 0 \\
\hline
\end{tabular}

Tabel 2. Hubungan Variabel Bebas dengan Keluhan Pernapasan pada pekerja

\begin{tabular}{lcc}
\hline \multicolumn{1}{c}{ Variabel Bebas } & Nilai C & Keterangan \\
\hline Umur & 0,535 & Hubungan Kuat \\
Masa Kerja & 0,509 & Hubungan Kuat \\
Kebiasaan Merokok & 0,412 & Hubungan Sedang \\
Kebiasaan Olahraga & 0,432 & Hubungan Sedang \\
\hline
\end{tabular}

\section{PEMBAHASAN}

Kapasitas fisik mulai sedikit menurun pada usia 30 tahun dan terus menurun seiring dengan bertambahnya umur. Penurunan terbanyak menjelang usia 60 tahun, penurunan tidak hanya terjadi pada otot tetapi diikuti penurunan kemampuan saraf, panca indera dan organ-organ lain seperti jantung dan paru yang mengakibatkan penurunan kapasitas fisik seseorang.

Menurut Tarwaka, dkk (2004) kemampuan fisik optimal seseorang dicapai pada saat usia 25-30 tahun dan kapasitas fisiologis seseorang akan menurun $1 \%$ tiap tahunnya setelah kondisi puncak terlampaui, pada saat ini manusia secara progresif akan kehilangan daya tahan terhadap penyakit degeneratif dan infeksi.
Tabel 3. Hubungan Variabel Bebas dengan Keluhan Muskuloskeletal pada pekerja

\begin{tabular}{lcc}
\hline \multicolumn{1}{c}{ Variabel Bebas } & Nilai C & Keterangan \\
\hline Umur & - & Tidak Ada Hubungan \\
Masa Kerja & - & Tidak Ada Hubungan \\
Kebiasaan Merokok & - & Tidak Ada Hubungan \\
Kebiasaan Olahraga & - & Tidak Ada Hubungan \\
Sikap Kerja & - & Tidak Ada Hubungan \\
Duduk Statis & 0,544 & Hubungan Kuat \\
Berdiri Statis & 0,559 & Hubungan Kuat \\
Posisi Tubuh & 0,559 & Hubungan Kuat \\
\hline
\end{tabular}

Nurmianto (2004) menyatakan bahwa puncak kekuatan otot pada laki-laki maupun perempuan dicapai pada umur 25-30 tahun. Pada pekerja, umur 50-60 tahun hanya menghasilkan kekuatan otot sebesar $75-85 \%$. Menurut Tarwaka (2004), mengatakan bahwa pada umur 25-30 tahun, kekuatan fisik seseorang mencapai pada titik optimal dan setelah titik optimalnya terlampaui maka akan terjadi penurunan kapasitas fisiologis hingga $1 \%$ per tahun sehingga tubuh lebih rentan terhadap penyakit infeksi dan penyakit degeneratif, pendapatnya yang lain adalah pada usia 25-64 tahun, pekerja mulai mengalami keluhan pada otot. Keluhan pertama biasanya dialami saat berusia 35 tahun dan tingkat keluhan akan semakin parah sejalan dengan bertambahnya usia.

Studi yang dilakukan oleh Hadler (2005) pada pekerja di Swedia menunjukkan hasil bahwa, penderita nyeri punggung mayoritas berusia 35-40 tahun (70\%). Hal ini terjadi karena pada umur setengah baya, kekuatan dan ketahanan otot mulai menurun. Pada saat kekuatan dan ketahanan otot menurun, maka risiko terjadinya keluhan semakin meningkat.

Hasil penelitian diperoleh hasil antara lain sebagian besar berusia muda yaitu 19-27 tahun $(46,43 \%)$. Berdasarkan nilai koefisien kontingensi, ada hubungan kuat antara keluhan pernapasan dengan umur dan tidak ada hubungan antara keluhan muskuloskeletal dengan umur.

Hasil tersebut menunjukkan bahwa sebagian besar pekerja tidak berisiko mengalami keluhan muskuloskeletal. Hasil lain menunjukkan bahwa ada hubungan antara faktor umur dengan keluhan pernapasan, hal tersebut dapat disebabkan 
adanya faktor lain yang tidak ikut diteliti namun memengaruhi hasil penelitian (faktor gizi kerja, riwayat penyakit, beban kerja).

Masa kerja merupakan salah satu faktor risiko terjadinya musculoskeletal disorders, terutama untuk jenis pekerjaan yang menggunakan kekuatan kerja yang tinggi. Menurut Riihimaki et al. dalam Tarwaka (2004) menjelaskan bahwa masa kerja mempunyai hubungan yang kuat dengan keluhan otot. Semakin lama masa kerja seseorang berarti semakin lama orang tersebut terpapar sumber bahaya di tempat kerja, maka seseorang akan menjadi semakin rentan terhadap gangguan kesehatan yang dapat ditimbulkan dari pekerjaannya.

Kreitner dan Kinicki (2004) menyatakan bahwa, masa kerja yang lama akan cenderung membuat seorang pegawai lebih merasa betah dalam suatu organisasi, hal ini disebabkan diantaranya karena telah beradaptasi dengan lingkungannya yang cukup lama sehingga seorang pegawai akan merasa nyaman dengan pekerjaannya.

Menurut Haeny (2009) pekerja dengan lama kerja lebih dari 3 tahun mempunyai faktor risiko lebih tinggi untuk terjadinya kelelahan dan keluhan otot dibandingkan masa kerja kurang dari atau sama dengan 3 tahun.

Hasil penelitian diperoleh hasil antara lain sebagian besar pekerja sudah bekerja selama 1 sampai 5 tahun $(46,43 \%)$. Berdasarkan nilai koefisien kontingensi, ada hubungan kuat antara keluhan pernapasan dengan masa kerja dan tidak ada hubungan antara keluhan muskuloskeletal dengan masa kerja. Hasil tersebut menunjukkan bahwa sebagian besar pekerja tidak berisiko untuk mengalami keluhan muskuloskeletal. Hasil lain dengan menunjukkan bahwa pekerja berisiko mengalami keluhan pada pernapasan, hal tersebut tidak sesuai dengan teori yang ada.

Dari hasil observasi yang sudah dilakukan diketahui bahwa area kerja memiliki ventilasi yang buruk dan tidak terpisah antar unit kerja sehingga paparan bahan kimia dalam lem. Sepatu dapat dengan mudah ke seluruh ruangan, akibatnya pekerja memiliki risiko lebih besar untuk mengalami keluhan pernapasan. Merokok dapat menyebabkan perubahan struktur dan fungsi saluran napas dan jaringan paru-paru. Pada saluran napas besar, sel mukosa membesar (hipertrofi) dan kelenjar mucus bertambah banyak (hiperplasia). Pada saluran napas kecil, terjadi radang ringan hingga penyempitan akibat bertambahnya sel dan penumpukan lendir.
Pada jaringan paru-paru, terjadi peningkatan jumlah sel radang dan kerusakan alveoli. Akibatnya terjadi perubahan anatomi saluran napas.

Menurut Frasser (1990), asap rokok dapat mengakibatkan proteolisis serta menghambat elastisitas jaringan paru sehingga terjadi degenerasi jaringan parenkim tanpa disertai pemulihan yang memadai. Merokok dapat menyebabkan perubahan struktur jalan nafas. Perubahan struktur jalan nafas besar adalah berupa hipertrofi dan hyperplasia pada kelenjar mucus. Sedangkan perubahan struktur jalan nafas kecil bervariasi, terjadi hyperplasia sel goblet dan penumpukan secret intraluminar. Perubahan struktur karena merokok sebagian besar disebabkan terjadi perubahan/kerusakan fungsi pada sel perokok berat berisiko memiliki angka harapan hidup 0,9 tahun lebih cepat dibandingkan perokok ring.

Asap rokok juga menunjukkan pengaruh ganda terhadap elastisitas jaringan paru, sehingga sebagai akibatnya terjadi degradasi parenkim paru tanpa pemulihan yang memadai (Higgins,1989).

Masalah sakit punggung lebih banyak diderita oleh Perokok aktif bila dibandingkan dengan perokok pasif. Efeknya adalah hubungan dosis yang lebih kuat dari pada yang diharapkan dari efek batuk risiko meningkat sekitar $20 \%$ untuk setiap 10 batang rokok per harinya (Pheasant, 1991).

Menurut survey yang dilakukan di Britania oleh Palmer et al (1996) ditemukan 13.000 orang yang merokok sering mengeluhkan rasa tidak nyaman pada musculoskeletal dan rasa lumpuh terhadap cidera musculoskeletal dibandingkan mereka yang tidak pernah merokok. Hal ini disebabkan rokok dapat merusak jaringan otot dan mengurangi respons syaraf terhadap rasa sakit. Menurut penelitian yang dilakukan Boshuizen et al. (1993), diperoleh hubungan yang signifikan antara kebiasaan merokok dengan keluhan otot pinggang, khususnya untuk pekerja yang memerlukan pengerahan otot. Kebiasaan merokok dapat menurunkan kapasitas paru, sehingga mengurangi kemampuan untuk mengonsumsi oksigen.

Hasil penelitian diperoleh hasil antara lain bahwa sebagian besar pekerja tidak merokok yaitu sebesar $67,86 \%$. Berdasarkan nilai koefisien kontingensi, ada hubungan sedang keluhan pernapasan dengan kebiasaan merokok dan tidak ada hubungan antara keluhan muskuloskeletal dengan kebiasaan merokok. Hasil tersebut menunjukkan bahwa sebagian besar tidak berisiko mengalami keluhan muskuloskeletal. Hasil lain dengan 
menunjukkan bahwa pekerja berisiko mengalami keluhan pada pernapasan, hal tersebut tidak sesuai dengan teori yang ada. Dari hasil observasi yang sudah dilakukan diketahui bahwa area kerja memiliki ventilasi yang buruk dan tidak terpisah antar unit kerja sehingga paparan bahan kimia dalam lem sepatu dapat dengan mudah ke seluruh ruangan, akibatnya pekerja memiliki risiko lebih besar untuk mengalami keluhan pernapasan.

Olahraga dapat meningkatkan tekanan darah, tekanan sistolik naik lebih tinggi daripada tekanan diastolik. Peningkatan tekanan darah sistolik diakibatkan oleh kenaikan curah jantung. Selain peningkatan tekanan darah, olahraga juga dapat meningkatkan ventilasi paru yang disebabkan kenaikan volume tidal, sedangkan pada olahraga yang berat kenaikan volume paru juga disebabkan oleh meningkatnya frekuensi pernapasan.

Menurut Cady (1979) dalam Tarwaka (2014) risiko terjadinya keluhan otot akan meningkat apabila kesegaran tubuh yang dimiliki rendah, selain itu keluhan otot akan meningkat sesuai dengan aktivitas fisik yang dilakukan. Kebiasaan olahraga dapat meningkatkan kesegaran tubuh karena dapat memperlancar aliran darah dalam tubuh dan meningkatkan volume tidal pada paru. Berdasarkan uraian di atas diketahui bahwa sebagian besar pekerja lebih berisiko mengalami keluhan pada otot dan pernapasan.

Berolahraga teratur dapat mengefisienkan kinerja otot-otot tubuh, seperti otot jantung, otot pernapasan dan otot-otot rangka tubuh, dan lebih melancarkan aliran darah ke dalam sel-sel tubuh, dan pembuangan bahan-bahan sisa dari sel-sel tubuh menjadi lebih baik. Olahraga dinamis mampu meningkatkan aliran darah sehingga sangat menunjang pemeliharaan jantung dan sistem pernapasan (Kuswana, 2007).

Pada pekerja dengan kekuatan fisik yang rendah memiliki risiko tiga kali lipat dibandingkan dengan kekuatan fisik yang tinggi (Ariani, 2009). Menurut Kusmana (2007) menjelaskan bahwa olahraga yang baik adalah marathon, tenis, mendayung $2000 \mathrm{~m}$, berenang $400 \mathrm{~m}$, panahan, lari gawang $200-800 \mathrm{~m}$, skate $10.000 \mathrm{~m}$, jogging dan jalan cepat, lari $1-5 \mathrm{~km}$, dan olahraga aerobik lainnya. Olahraga tersebut baik untuk kesehatan jantung dan peredaran darah.

Hasil penelitian diperoleh hasil antara lain sebagian besar pekerja tidak memiliki kebiasaan olahraga $(67,86 \%)$. Berdasarkan nilai koefisien kontingensi, ada hubungan sedang antara keluhan pernapasan dengan kebiasaan olahraga dan tidak ada hubungan antara keluhan muskuloskeletal dengan kebiasaan olahraga.

Hasil tersebut menunjukkan bahwa sebagian besar pekerja tidak berisiko mengalami keluhan muskuloskeletal. Hasil lain dengan menunjukkan bahwa pekerja berisiko mengalami keluhan pada pernapasan, hal tersebut tidak sesuai dengan teori yang ada. Hal tersebut dapat disebabkan faktor lain yang memengaruhi keluhan pernapasan namun tidak diteliti seperti riwayat penyakit, gizi kerja, dan beban kerja.

Posisi tubuh saat bekerja sangat ditentukan oleh jenis pekerjaan yang dilakukan. Masing-masing posisi tubuh memberikan pengaruh yang berbeda terhadap tubuh. Sikap kerja duduk memerlukan energi yang lebih sedikit daripada sikap berdiri sehingga beban pada otot statis dapat dikurangi (Nurmianto, 2003).

Bekerja dengan posisi duduk memiliki beberapa keuntungan antara lain dapat mengurangi beban pada kaki dan pemakaian energi untuk sirkulasi darah. Namun pada sikap duduk yang terlalu lama dapat berdampak melembeknya otot perut, tulang belakang menjadi melengkung yang dapat mengakibatkan cepat lelah (Grandjean, 1993)

Hasil penelitian menunjukkan bahwa sebagian besar pekerja bekerja dengan duduk $(50,00 \%)$. Berdasarkan nilai koefisien kontingensi, tidak ada hubungan antara keluhan muskuloskeletal dan sikap kerja. Hasil tersebut tidak sesuai dengan teori yang ada, hal tersebut dapat disebabkan karena sikap kerja tersebut tidak dilakukan dalam waktu yang lama sehingga hasil menunjukkan tidak ada hubungan.

Sikap duduk yang baik adalah duduk dengan posisi punggung lurus dan bahu berada di belakang serta bahu menyentuh belakang kursi. Posisi lutut sama tinggi atau lebih tinggi dari panggul (dengan menggunakan pijakan kaki) agar kaki tidak menggantung, serta posisi tungkai tidak saling menyilang. Usahakan untuk mengubah posisi tubuh setiap 20-30 menit dan jaga bahu dan tangan agar tetap rileks (Nurmianto, 2003).

Menurut Siswanto (1995), desain tempat duduk harus dibuat sedemikian rupa sehingga otot-otot yang sering dipakai dapat berelaksasi dan tidak menimbulkan penekanan pada bagian tubuh yang dapat mengganggu peredaran darah dan sensibilitas pada bagian tubuh. 
Menurut penelitian yang dilakukan oleh Samara dkk (2005) diperoleh hasil bahwa pekerja yang melakukan pekerjaan duduk pada posisi tubuh yang tegak memiliki tekanan yang lebih besar pada diskus intervertebralis antara lumbal ke-3 dan 4, yaitu sebesar 1,4 kali lebih besar dibandingkan dengan posisi berdiri tegak. Pada posisi duduk membungkuk memiliki tekanan pada diskus intervertebralis antara lumbal ke-3 dan 4 sebesar 1,9 kali lebih besar bila dibandingkan saat berdiri dengan posisi tegak.

Penelitian yang dilakukan diperoleh hasil bahwa sebagian besar pekerja, bekerja dengan duduk di lantai $(50,00 \%)$. Berdasarkan nilai koefisien kontingensi, ada hubungan kuat antara duduk statis dengan keluhan muskuloskeletal. Pada saat bekerja dengan posisi duduk di lantai, sebagian besar pekerja bekerja dengan posisi canggung (awkward position) yaitu dengan punggung membungkuk, kaki menyilang atau saling menekan. Posisi canggung disebabkan oleh respons tubuh pekerja untuk menyesuaikan diri pada tempat kerja. Seringkali posisi canggung tersebut dipertahankan dalam jangka waktu yang lama karena area kerja yang tidak terlalu luas dan pekerjaan yang mengharuskan untuk duduk dalam jangka waktu lama. Dampaknya adalah banyak pekerja yang mengalami keluhan pada daerah punggung, pinggang, betis dan lain-lain. Hal ini sejalan dengan pendapat para ahli.

Bekerja dengan sikap kerja berdiri dalam waktu yang lama akan membuat pekerja berusaha menyeimbangkan posisi tubuh sehingga menyebabkan otot-otot pada leher, punggung, paha dan kaki mengalami kontraksi statis. Otot yang mengalami kontraksi statis, mengakibatkan pembuluh-pembuluh darah tertekan karena dalam otot terjadi pertambahan tekanan. Kondisi tersebut mengakibatkan peredaran di dalam otot menjadi berkurang, selain itu kondisi tersebut juga mengakibatkan penumpukan pembuluh darah pada bagian bawah tubuh yaitu pada kaki.

Menurut Sutalaksana (2000) dalam Tarwaka (2010) mengatakan bahwa sikap kerja berdiri merupakan sikap kerja siaga baik fisik dan mental, sehingga aktivitas yang dilakukan menjadi lebih cepat, lebih teliti. Akan tetapi pada sikap kerja berdiri khususnya yang menggunakan alat, dapat mengakibatkan cepat lelah karena energi yang dikeluarkan pada saat berdiri lebih besar 10-15\% bila dibandingkan dengan sikap kerja duduk.

Menurut Pulat (1992) dan Clark (1996) dalam Tarwaka (2010) menjelaskan beberapa pertimbangan yang perlu diperhatikan saat melakukan sikap kerja berdiri, yaitu pekerjaan yang dilakukan mengharuskan untuk memegang obyek yang berat (lebih dari 4,5 kg); pekerjaan yang dilakukan berupa pekerjaan yang sering menjangkau benda ke atas, ke bawah dan ke samping; pekerjaan tersebut memerlukan mobilitas yang tinggi serta pekerjaan yang sering dilakukan berupa pekerjaan yang membutuhkan penekanan ke bawah.

Bekerja dengan menggunakan meja dapat mencegah tubuh untuk bekerja dengan sikap kerja paksa yaitu posisi tubuh membungkuk. Posisi tubuh yang terlalu membungkuk dapat menimbulkan rasa sakit pada kepala, mata, leher, punggung, dan pinggang. Bekerja dengan sikap kerja berdiri dalam waktu yang lama akan membuat pekerja berusaha menyeimbangkan posisi tubuh sehingga menyebabkan otot-otot pada leher, punggung, paha dan kaki mengalami kontraksi statis.

Penelitian yang dilakukan oleh Suwarno (2005) pada pengrajin ukir di Bali, diperoleh hasil antara lain pekerja yang menggunakan meja kerja pada saat bekerja dengan sikap kerja berdiri, mengalami penurunan keluhan pada leher sebesar $100 \%$, pada bahu kiri sebesar 33,3\%, pada bahu kanan sebesar $66,6 \%$, pada punggung sebesar $100 \%$, pada pinggang sebesar $100 \%$ dan pada pantat sebesar $66,6 \%$. Penelitian lainnya dilakukan oleh Sutajaya (1997) pada pematung di Desa Pliatan, Ubud Bali. Pada penelitian tersebut, diperoleh hasil bahwa penggunaan meja kerja dapat menurunkan keluhan muskulosketal sebesar 23,37\%.

Penelitian yang dilakukan, diperoleh hasil sebagian besar pekerja yang berdiri, bekerja dengan menggunakan meja $(14,28 \%)$. Berdasarkan nilai koefisien kontingensi, ada hubungan sebagian besar bekerja dengan menggunakan meja. Bekerja dengan posisi antara berdiri statik dengan keluhan muskuloskeletal. Sikap kerja berdiri sebagian besar menggunakan meja yang tidak standar karena letaknya terlalu tinggi bagi pekerjaan yang membutuhkan tekanan, akibatnya banyak pekerja yang mengalami keluhan terutama pada bagian bahu dan lengan. Hasil tersebut sudah sesuai dengan pendapat para ahli.

Sikap kerja tidak alamiah adalah sikap kerja dimana bagian-bagian tubuh bergerak menjauhi posisi alamiah. Sikap kerja tidak alamiah meliputi mengangkat tangan, punggung terlalu membungkuk, kepala terangkat dan sebagiannya. Semakin jauh posisi bagian tubuh menjauhi posisi alamiah maka 
semakin tinggi risiko untuk mengalami keluhan pada otot (Grandjean, 1993; Anis \& McCnville, 1996; Waters \& Anderson, $1996 \&$ Manuaba, 2000).

Menurut Harkness dkk (2003) dalam Samara (2010) menjelaskan bahwa posisi tubuh dibagi menjadi tiga kelompok yaitu posisi tubuh tegak, posisi tubuh membungkuk dan posisi pinggang memutar. Posisi tubuh tegak digunakan sebagai rujukan karena dianggap sebagai posisi yang paling sedikit risiko keluhan muskuloskeletal.

Menurut Santoso (2007) menjelaskan sikap duduk yang baik adalah dengan tulang badan dan tulang belakang pada saat duduk, dengan sedikit lordosa (tulang punggung ke depan). Posisi pinggang sedikit mungkin skifosa (sikap duduk ke belakang) pada punggung. Sikap duduk yang baik dapat terpenuhi dengan menggunakan kursi yang memiliki sandaran punggung yang tepat.

Penelitian yang dilakukan oleh Samara dkk (2005), diperoleh hasil bahwa pekerja bekerja dengan posisi tubuh membungkuk minimal 600 dan dilakukan $>5 \%$ dari total jam kerja mempunyai risiko 1,5 kali untuk mengalami keluhan muskuloskeletal khususnya keluhan pada punggung bawah. Posisi kerja yang memutar minimal 300 dan dilakukan $>10 \%$ dari total jam kerja, berisiko mengalami keluhan muskuloskeletal khususnya keluhan pada punggung bawah yaitu sebesar 1,3 kali. Bekerja dengan posisi tubuh membungkuk dapat menimbulkan rasa sakit pada kepala, mata, leher, punggung, dan pinggang.

Berdasarkan hasil penelitian, diketahui bahwa sebagian besar bekerja posisi punggung tegak $(14,28 \%)$ dan dari nilai koefisien kontingensi didapatkan hubungan kuat antara postur kerja dengan keluhan muskuloskeletal. Posisi punggung tegak memiliki risiko yang paling kecil untuk mengalami keluhan muskuloskeletal khususnya keluhan punggung bawah. Apabila sikap tubuh ini dipertahankan dalam jangka waktu yang lama dapat menimbulkan kelelahan yang lebih cepat dibandingkan dengan posisi punggung yang membungkuk. Hasil ini sesuai dengan pendapat para ahli.

\section{SIMPULAN}

Pekerja sepatu sebagian besar berusia 19-27 tahun, memiliki masa kerja 1 sampai 5 tahun dan tidak rajin berolahraga. Umur pekerja berhubungan dengan keluhan muskuloskeletal pada pekerja sepatu. Berdasarkan hasil penelitian diperoleh ada hubungan kuat antara keluhan muskuloskeletal dengan umur, masa kerja, sikap kerja duduk dan postur kerja. Terdapat hubungan sedang antara keluhan musculoskeletal dengan kebiasaan olahraga.

\section{DAFTAR PUSTAKA}

Amin. 1996. Penyakit Paru Obstruktif Menahun: Polusi Udara, Rokok dan Alfa-1 Antitipsin. Skripsi. Surabaya: Airlangga University Press.

Aprisindo. 2008. Aprisindo News. Jakarta: Asosiasi Persepatuan Indonesia.

Bhaskara,W.R. dan Arief R. Studi Postur dan Gerak Dinamis Menggunakan Permodelan dan Simulasi Gerak 3D Berbasis Skeletal System. Skripsi. Surabaya: Fakultas Teknik Industri Institut Teknologi Sepuluh November.

Bridger, R.S. 1995. Introduction to Ergonomics. International Editions. General Engineering Series. McGraw-Hill, Inc.

Didin. 2007. Lem Kuning dapat Menyebabkan Leukimia. http://nbudiman.blogspot.com/2007 /09/lem-kuning-dapat-menyebabkan-leukimia.html. (Sitasi 25 Februari 2014).

Grandjean, E.1993. Fitting the Task to the Man, 4th ed. London: Taylor and Francis, inc.

Hamilton. 2005. Dasar-dasar Keperawatan Maternitas. Jakarta: EGC.

Hanne, C., Mikkel, B.P., dan Gisela S. 1995. A National Cross Sectional Study in the Danish Wood and Furniture Industry on Working Posture and Manual Handling. Ergonomics, Vol. 38, No. 4, p. 793-805.

Hendra. Peningkatan Pengetahuan Pengrajin Sepatu Informal tentang Bahaya Kimia dan Cara Kerja Aman dengan Bahan Kimia. Skripsi. Jakarta: Lembaga Penelitian Universitas Indonesia.

Humantech. 1995. Applied Ergonomics Training Manual 2nd Edition. Australia: Berkeley Vale.

Kusmana, Dede. Faktor Risiko Penyakit Jantung. http://www.yayasanmdf.org/home/index. (sitasi 6 November 2013. 